\title{
Toxicity of some insecticides used in maize crop on Trichogramma pretiosum (Hymenoptera, Trichogrammatidae) immature stages
}

\author{
Jander R. Souza ${ }^{1}$, Geraldo A. Carvalho ${ }^{1}$, Alexandre P. Moura ${ }^{2 *}$, Marcelo H.G. Couto ${ }^{1}$, \\ and Jader B. Maia ${ }^{1}$
}

Fall armyworm Spodoptera frugiperda (J.E. Smith, 1797) (Lepidoptera: Noctuidae) is an important pest of maize (Zea mays L.) crops in Brazil. The effects of beta-cypermethrin, chlorfenapyr, chlorpyrifos, spinosad, etofenprox, triflumuron, alpha-cypermethrin/teflubenzuron, and lambda-cyhalothrin/thiamethoxam on Trichogramma pretiosum Riley, 1879 (Hymenoptera: Trichogrammatidae) immature stages were evaluated. Eggs of Anagasta kuehniella (Zeller, 1879) (Lepidoptera: Pyralidae), containing immature stages of the parasitoid were dipped in water solution pesticides, to evaluate their effects on emergence and sex ratio of $F_{1}$ parasitoids. For $F_{2}$ parasitoids, emergence, parasitism capacity, and sex ratio were evaluated. Beta-cypermethrin, chlorfenapyr, chlorpyrifos, and spinosad affected the emergence success of $F_{1}$ T. pretiosum. Insects exposed to etofenprox and alpha-cypermethrin/teflubenzuron during the egg-larval period and to lambda-cyhalothrin/thiamethoxam during the pupal stage also suffered reduction in the emergence. Beta-cypermethrin affected the sex ratio of $F_{1}$ T. pretiosum from host eggs treated during the egg-larval period; spinosad affected it during the egg-larval period and the pupal stage, whereas chlorpyrifos did the same when applied during the pupal stage. Chlorpyrifos also affected the sex ratio of $\mathrm{F}_{2}$ parasitoids, but only when applied during the egg-larval period, whereas chlorfenapyr reduced this trait when applied during the pre-pupal phase. Chlorpyrifos and alpha-cypermethrin/teflubenzuron affected the parasitism capacity of $F_{1}$ females from eggs treated during the egg-larval period. Considering the overall effects, only etofenprox and triflumuron were selective on T. pretiosum when applied on parasitized A. kuehniella eggs. Further studies need to be carried out to verify the toxicity of the other pesticides under semi-field and field conditions.

Key words: Anagasta kuehniella, biological control, natural enemies, selectivity, Zea mays.

\section{INTRODUCTION}

In Brazil, maize (Zea mays L.) crop occupied about 14.2 million hectares in 2012, ensuring a production of approximately 71.3 million tons. The States of Paraná, Mato Grosso, Goiás, Minas Gerais, and Mato Grosso do Sul are the biggest producers and hold the largest planted areas with this crop, responding for around $76 \%$ of the Brazilian production (IBGE/LSPA, 2013).

Among the insect pests attacking the maize crop, the fall armyworm Spodoptera frugiperda (J.E. Smith, 1797) (Lepidoptera, Noctuidae) is considered the main one, occurring practically throughout the whole crop cycle. In Brazil, it is estimated that the fall armyworm is responsible for losses that exceed $50 \%$ of the damages caused by all insect pests and for most spending with pesticides (Figueiredo et al., 2006).

${ }^{1}$ Universidade Federal de Lavras, Departamento de Entomologia, 37200-000, Caixa Postal 3037, Lavras, Minas Gerais, Brasil.

${ }^{2}$ Empresa Brasileira de Pesquisa Agropecuária - EMBRAPA, Embrapa Hortaliças, 70351-970, Caixa Postal 218, Brasília, DF, Brasil. "Corresponding author (alexandre.moura@embrapa.br).

Received: 11 June 2013.

Accepted: 24 January 2014.

doi:10.4067/S0718-58392014000200016
Besides the chemical method, another way of managing lepidopteran pests in maize crops is by mean of the use of biological control with egg parasitoids of the genus Trichogramma, which control insect before they can cause crop damage. In Brazil, 26 species of Trichogramma have been recorded (Querino and Zucchi, 2005; Zucchi et al., 2010; Querino and Zucchi, 2011), among them Trichogramma pretiosum Riley, 1879 (Hymenoptera, Trichogrammatidae), which is widely distributed around the country and is associated to several hosts, including $S$. frugiperda (Beserra and Parra, 2003).

However, combining the use of pesticides and biological control agents against insect pests in maize, without affecting beneficial fauna, is necessary to identify and/or develop selective compounds, and to determine the factors that can affect behavior, development, and reproduction of these organisms (Moura et al., 2010). Thus, studies on pesticide selectivity to beneficial are warranted to produce information for decision-making in integrated pest management (IPM) programs and to ensure the action of these organisms in agroecosystems, allowing them to regulate populations of insect pests (Moura et al., 2005).

In this context, this study evaluated the toxicity against the egg parasitoid T. pretiosum at several developmental 
immature stages of some insecticides recommended for $S$. frugiperda control in maize.

\section{MATERIALS AND METHODS}

Insecticides ( $\mathrm{g}$ ai $\mathrm{L}^{-1}$ ) used in the bioassays with $T$. pretiosum were beta-cypermethrin (cyano(3phenoxyphenyl)methyl 3-(2,2-dichloroethenyl)-2,2dimethylcyclopropanecarboxylate) (0.03), chlorfenapyr (4-bromo-2-(4-chlorophenyl)-1-ethoxy methyl-5trifluoromethyl-1H-pyrrole-3-carbonitrile) $\quad(0.60)$, chlorpyrifos $(O, O$-diethyl $O$-3,5,6-trichloro-2-pyridyl phosphorothioate) (0.96), spinosad (mixture of 50-95\% $(2 R, 3 \mathrm{a} S, 5 \mathrm{a} R, 5 \mathrm{~b} S, 9 S, 13 S, 14 R, 16 \mathrm{a} S, 16 \mathrm{~b} R)$-2-(6-deoxy2,3,4-tri- $O$-methyl- $\alpha$-L-mannopyranosyloxy)-13-(4dimethylamino- $2,3,4,6$-tetradeoxy- $\beta$-D-erythropyranosyloxy)-9-ethyl-2,3,3a,5a,5b,6,7,9,10,11,12,13,14,15,1 6a,16b-hexadecahydro-14-methyl-1H-as-indaceno[3,2-d] oxacyclododecine-7,15-dione and 50-5\% (2S,3aR,5aS,5b $S, 9 S, 13 S, 14 R, 16 \mathrm{a} S, 16 \mathrm{~b} S)$-2-(6-deoxy-2,3,4-tri- $O$-methyl$\alpha$-L-mannopyranosyloxy)-13-(4-dimethylamino-2,3,4,6tetradeoxy- $\beta$-D-erythropyranosyloxy)-9-ethyl-2,3,3a,5 a , $5 b, 6,7,9,10,11,12,13,14,15,16 a, 16 b$-hexadecahydro4,14-dimethyl- $1 \mathrm{H}$-as-indaceno[3,2-d]oxacyclododecine7,15-dione) (0.16), etofenprox (2-(4-ethoxyphenyl)-2methylpropyl 3-phenoxybenzyl ether) (0.10), triflumuron (1-(2-chlorobenzoyl)-3-(4-trifluoromethoxyphenyl)urea) (0.08), alpha-cypermethrin $((R)$-cyano(3-phenoxyphenyl) methyl (1S,3S)-rel-3-(2,2-dichloroethenyl)-2,2-dimethylc yclopropanecarboxylate)/teflubenzuron (1-(3,5-dichloro2,4-difluorophenyl)-3-(2,6-difluorobenzoyl)urea) $(0.0425 / 0.0425)$, and lambda-cyhalothrin $((R)$-cyano(3phenoxyphenyl)methyl (1S,3S)-rel-3-[(1Z)-2-chloro3,3,3-trifluoro-1-propen-1-yl]-2,2-dimethylcycloprop anecarboxylate)/thiamethoxam ((EZ)-3-(2-chloro-1,3thiazol-5-ylmethyl)-5-methyl-1,3,5-oxadiazinan-4ylidene(nitro)amine) $(0.11 / 0.083)$. The dosages used were the highest recommended by manufacturers for controlling $S$. frugiperda in maize. Distilled water was used as control.

Thirty $T$. pretiosum females aged up to $24 \mathrm{~h}$ obtained from rearing were set individually into glass tubes $(8 \mathrm{~cm}$ $\times 2.5 \mathrm{~cm}$ diameter), which were closed with a PVC film and fed with a little drop of honey applied on the inner walls of the tubes. Parasitoids were reared as described by Moura et al. (2005).

Eggs ( $\cong 125$ eggs per card per female) of the factitious host Anagasta kuehniella (Zeller, 1879) (Lepidoptera, Pyralidae) previously UV-killed, with up to $24 \mathrm{~h}$ of age, were glued with diluted Arabic gum to a blue paper card $(8 \mathrm{~cm} \times 0.5 \mathrm{~cm})$ and exposed to parasitism. After $24 \mathrm{~h}$, female parasitoids were discarded and parasitized host eggs were transferred to clean vials, which were kept at $25 \pm 2{ }^{\circ} \mathrm{C}, \mathrm{RH} 70 \pm 10 \%$, with $12: 12$ h photophase until the parasitoids reached the desired developmental stage (egg-larval $=0$ - $24 \mathrm{~h}$; pre-pupal $=72-96 \mathrm{~h}$; pupal $=168$ -
192 h) (Cônsoli et al., 1999; 2001). The factitious host was reared on a diet based on whole wheat flour $(97 \%)$ and brewer's yeast (3\%) (Parra, 1997).

Thirty blue paper cards with parasitized host eggs were treated per treatment by dipping the cards into the insecticide water solutions or water (control) for $5 \mathrm{~s}$ after they have reached desired developmental stages. After treatment, cards were air dried at room temperature, transferred to new vials and kept at the conditions described before. For each studied T. pretiosum immature stage, the treatment was replicated six times, each plot being composed of five cards with A. kuehniella eggs, totalizing 270 cards per development stage.

The effects of insecticide treatments on newly emerged adults from host eggs treated during the different immature stages of the parasitoid were also evaluated. Thus, $24 T$. pretiosum $\mathrm{F}_{1}$ females were set individually per treatment into glass tubes and fed as described before. For these females, blue paper cards holding $\cong 125$ newly laid untreated eggs per card per female were offered and allowed to parasitize for $24 \mathrm{~h}$. Then, the surviving females were discarded and the cards with the parasitized eggs were transferred to new glass vials and kept at the conditions described before, until adult $\left(\mathrm{F}_{2}\right)$ emergence. Each treatment was replicated six times and each plot was composed of four cards containing parasitized host eggs.

Assessment of mortality ( $\mathrm{F}_{1}$ emergence success) during the parasitoid immature development stages caused by the insecticides evaluated was quantified by calculating the ratio between the number of blacked eggs without emergence opening and the total number of parasitized eggs. Their side-effects on the parasitoid were also assessed by recording the parasitization capacity (number of eggs parasitized per female per $24 \mathrm{~h}$ period) of the $\mathrm{F}_{1}$ females, emergence success (ratio between number of blacked eggs without emergence opening and the total number of parasitized eggs) and the sex ratio of $F_{1}$ and $F_{2}$ individuals.

A fully randomized experimental design, in a factorial scheme $3 \times 9$ (three immature development stages $\times$ nine treatments) was used. Obtained data were subjected to ANOVA and when the $F$-test was significant, treatment means were compared using the Scott-Knott clustering test (Scott and Knott, 1974) at 5\% significance, using the SAS statistical software (SAS Institute, 2001).

The tested insecticides were also classified into toxicological categories, based on the reduction (\%R) of the beneficial capacity of the parasitoid in relation to the control, according to recommendations proposed by members of the International Organization for Biological Control (IOBC) (Sterk et al., 1999), in four classes: class $1=$ harmless $(\% \mathrm{R}<30 \%$-either in the parasitization capacity or in the emergence success), class $2=$ slightly harmful $(30 \% \leq \% \mathrm{R}<80 \%)$, class $3=$ moderately harmful $(80 \% \leq \% \mathrm{R}<99 \%)$, and class $4=$ harmful $(\% \mathrm{R}$ $>99 \%)$. The reduction of the beneficial capacity of the 
parasitoid (parasitization capacity or emergence success) was obtained using the following equation:

Reduction $(\%)=100-$ [treatment mean/control mean] $\times 100$

\section{RESULTS}

The insecticides beta-cypermethrin, chlorfenapyr, chlorpyrifos, and spinosad reduced the emergence success of $T$.pretiosum $\left(\mathrm{F}_{1}\right)$ when the host eggs were treated during any immature development stage (Table 1); however, beta-cypermethrin was more toxic during the egg-larval period (96.9\% reduction), whereas chlorpyrifos had a greater effect when applied on the pupal stage $(92.3 \%$ reduction) of the parasitoid. Etofenprox and alphacypermethrin/teflubenzuron also reduced the emergence success of $T$. pretiosum, but only when applied on host eggs containing the egg-larval period. On the other hand, lambda-cyhalothrin/thiamethoxam only affected this biological characteristic when applied on the pupal stage. Triflumuron was innocuous to this parasitoid, regardless of the treated immature stage.

Based on the reductions caused to the $F_{1}$ emergence success of $T$. pretiosum, spinosad was classified as moderately harmful (class 3 ), while etofenprox, triflumuron, and alpha-cypermethrin/teflubenzuron were considered harmless (class 1), regardless of the treated immature stage (Table 1). On the other hand, lambda-cyhalothrin/ thiamethoxam was considered harmless (class 1) to the egglarval and pre-pupal stages, and slightly harmful (class 2) to the pupal stage. Beta-cypermethrin was classified as moderately harmful (class 3) during egg-larval period and slightly harmful (class 2) to pre-pupae and pupae, whereas both chlorfenapyr and chlorpyrifos were slightly harmful (class 2) to the egg-larval and pre-pupal stages, and harmless (class 1) and moderately harmful (class 3), respectively, to the pupal stage.

Sex ratio of $F_{1}$ adults from surface-treated host eggs was not affected when the insecticides where applied during the pre-pupal stage of $T$. pretiosum (Table 2). Chlorfenapyr, etofenprox, triflumuron, alphacypermethrin/teflubenzuron, and lambda-cyhalothrin/ thiamethoxam also did not affect the sex ratio of $F_{1}$ adults
Table 2. Sex ratio ( $\pm \mathrm{SE}$ ) of Trichogramma pretiosum $\mathbf{F}_{1}$ from treated eggs of Anagasta kuehniella containing the parasitoids in the immature stages ${ }^{1}$.

\begin{tabular}{lccc}
\hline Treatment & Egg-larvae & Pre-pupae & Pupae \\
\hline Control & $0.60 \pm 0.04 \mathrm{aA}$ & $0.63 \pm 0.06 \mathrm{aA}$ & $0.66 \pm 0.09 \mathrm{aA}$ \\
Beta-cypermethrin & $0.12 \pm 0.12 \mathrm{cC}$ & $0.67 \pm 0.10 \mathrm{aA}$ & $0.53 \pm 0.15 \mathrm{aB}$ \\
Chlorfenapyr & $0.62 \pm 0.07 \mathrm{aA}$ & $0.68 \pm 0.05 \mathrm{aA}$ & $0.69 \pm 0.12 \mathrm{aA}$ \\
Chlorpyrifos & $0.54 \pm 0.06 \mathrm{aA}$ & $0.56 \pm 0.20 \mathrm{aA}$ & $0.11 \pm 0.09 \mathrm{cB}$ \\
Spinosad & $0.38 \pm 0.17 \mathrm{bA}$ & $0.49 \pm 0.26 \mathrm{aA}$ & $0.40 \pm 0.17 \mathrm{bA}$ \\
Etofenprox & $0.60 \pm 0.10 \mathrm{aA}$ & $0.60 \pm 0.10 \mathrm{aA}$ & $0.61 \pm 0.08 \mathrm{aA}$ \\
Triflumuron & $0.62 \pm 0.10 \mathrm{aA}$ & $0.66 \pm 0.09 \mathrm{aA}$ & $0.66 \pm 0.08 \mathrm{aA}$ \\
Alpha-cypermethrin/ & $0.54 \pm 0.08 \mathrm{aA}$ & $0.62 \pm 0.10 \mathrm{aA}$ & $0.57 \pm 0.15 \mathrm{aA}$ \\
teflubenzuron & & & \\
Lambda-cyhalothrin/ & $0.62 \pm 0.06 \mathrm{aA}$ & $0.67 \pm 0.07 \mathrm{aA}$ & $0.69 \pm 0.12 \mathrm{aA}$ \\
thiamethoxam & & & \\
\hline CV $\%=21.6$ & & & \\
\hline
\end{tabular}

$\mathrm{CV}, \%=21.6$

${ }^{1}$ Means followed by the same letter, lower-case in the column and uppercase in the row, are not different by the Scott-Knott test $(\mathrm{P}>0.05)$.

obtained from treated host eggs containing the egg-larval and pupal stages of this parasitoid. Beta-cypermethrin and chlorpyrifos reduced significantly the sex ratio of $T$. pretiosum just for adults from egg-larval and pupal stages, respectively, while spinosad affected this parameter during both the egg-larval and pupal stages.

Parasitism capacity of $\mathrm{F}_{1}$ T. pretiosum females from host eggs treated with chlorfenapyr, etofenprox, triflumuron, and lambda-cyhalothrin/thiamethoxam was not affected, and these insecticides were classified as harmless (class 1), regardless of the treated immature stage (Table 3). Alpha-cypermethrin/teflubenzuron reduced the number of parasitized eggs, but only for females from treated eggs containing the egg-larval period, and was considered as slightly harmful (class 2). The parasitism capacity of $T$. pretiosum females from treated egg-larvae within eggs of A. kuehniella was also affected by chlorpyrifos, which reduced the number of parasitized eggs per female in $~ 58 \%$ and was considered slightly harmful to the parasitoid. For both the pre-pupal and pupal stages the effects of chlorpyrifos on the parasitism capacity of $T$. pretiosum were not assessed, because this compound reduced in $75.9 \%$ and $92.3 \%$, respectively, the emergence success of this parasitoid species (Tables 1 and 3). The same was observed for beta-cypermethrin, but just for females from treated egg-larvae within host eggs. The

Table 1. Emergence success $(\%)$ ( \pm SE) of Trichogramma pretiosum $\left(\mathrm{F}_{1}\right)$ originated from treated eggs of Anagasta kuehniella containing the parasitoids in the immature stages, percentage of reduction (PR) in the emergence success, and toxicological classification according to International Organization for Biological Control (IOBC) members.

\begin{tabular}{|c|c|c|c|c|c|c|c|c|c|}
\hline Treatment & Egg-larvae $^{1}$ & $\mathrm{PR}^{2}$ & Class $^{3}$ & Pre-pupae $^{1}$ & $\mathrm{PR}^{2}$ & Class $^{3}$ & Pupae $^{1}$ & $\mathrm{PR}^{2}$ & Class $^{3}$ \\
\hline Control & $78.1 \pm 9.94 \mathrm{aA}$ & - & - & $79.2 \pm 6.42 \mathrm{aA}$ & - & - & $77.3 \pm 7.24 \mathrm{aA}$ & - & - \\
\hline Beta-cypermethrin & $2.4 \pm 2.49 \mathrm{~dB}$ & 96.9 & 3 & $46.0 \pm 10.02 \mathrm{bA}$ & 41.8 & 2 & $46.9 \pm 8.41 \mathrm{bA}$ & 39.3 & 2 \\
\hline Chlorfenapyr & $40.9 \pm 10.6 \mathrm{cB}$ & 47.5 & 2 & $46.3 \pm 5.60 \mathrm{bB}$ & 41.5 & 2 & $55.6 \pm 10.30 \mathrm{bA}$ & 28.0 & 1 \\
\hline Chlorpyrifos & $47.0 \pm 10.10 \mathrm{cA}$ & 39.8 & 2 & $19.0 \pm 10.02 \mathrm{cB}$ & 75.9 & 2 & $5.9 \pm 8.46 \mathrm{cC}$ & 92.3 & 3 \\
\hline Spinosad & $7.3 \pm 4.19 \mathrm{dA}$ & 90.6 & 3 & $11.0 \pm 4.30 \mathrm{cA}$ & 86.1 & 3 & $4.7 \pm 2.17 \mathrm{cA}$ & 93.9 & 3 \\
\hline Etofenprox & $63.8 \pm 14.81 \mathrm{bA}$ & 18.2 & 1 & $72.2 \pm 7.78 \mathrm{aA}$ & 8.8 & 1 & $76.6 \pm 8.47 \mathrm{aA}$ & 0.9 & 1 \\
\hline Triflumuron & $75.8 \pm 9.97 \mathrm{aA}$ & 2.9 & 1 & $75.5 \pm 12.91 \mathrm{aA}$ & 4.6 & 1 & $74.0 \pm 5.03 \mathrm{aA}$ & 4.2 & 1 \\
\hline Alpha-cypermethrin/teflubenzuron & $67.1 \pm 13.76 \mathrm{bA}$ & 14.1 & 1 & $77.7 \pm 7.53 \mathrm{aA}$ & 1.9 & 1 & $76.3 \pm 14.33 \mathrm{aA}$ & 1.3 & 1 \\
\hline Lambda-cyhalothrin/thiamethoxam & $82.2 \pm 2.36 \mathrm{aA}$ & 0.0 & 1 & $73.0 \pm 12.03 \mathrm{aA}$ & 7.9 & 1 & $44.4 \pm 10.07 \mathrm{bB}$ & 45.5 & 2 \\
\hline
\end{tabular}

$\mathrm{CV}, \%=17.4$

${ }^{1}$ Means followed by the same letter, lower-case in column and uppercase in row, are not different by the Scott-Knott test $(\mathrm{P}>0.05)$.

${ }^{2}$ Percentage of reduction in the emergence success

${ }^{3}$ Class of toxicity proposed by Sterk et al. (1999). 
Table 3. Parasitism capacity ( \pm SE) of $\mathrm{F}_{1}$ Trichogramma pretiosum females, from treated Anagasta kuehniella eggs containing the parasitoids in the immature stages, percentage of reduction (PR) in the parasitism capacity, and toxicological classification according to International Organization for Biological Control (IOBC) ${ }^{1}$.

\begin{tabular}{|c|c|c|c|c|c|c|c|c|c|}
\hline Treatment & Egg-larvae & $\mathrm{PR}^{2}$ & Class $^{3}$ & Pre-pupae $^{1}$ & $\mathrm{PR}^{2}$ & Class $^{3}$ & Pupae & $\mathrm{PR}^{2}$ & Class $^{3}$ \\
\hline Control & $30.2 \pm 7.33 \mathrm{aA}$ & - & - & $27.7 \pm 4.46 \mathrm{aA}$ & - & - & $30.0 \pm 5.80 \mathrm{aA}$ & - & - \\
\hline Beta-cypermethrin & - & - & - & $27.5 \pm 8.62 \mathrm{aA}$ & 0.7 & 1 & $30.9 \pm 3.87 \mathrm{aA}$ & 0.0 & 1 \\
\hline Chlorfenapyr & $25.6 \pm 1.18 \mathrm{aA}$ & 15.1 & 1 & $24.8 \pm 1.69 \mathrm{aA}$ & 10.6 & 1 & $24.1 \pm 1.03 \mathrm{aA}$ & 19.8 & 1 \\
\hline Chlorpyrifos & $12.5 \pm 3.78 b$ & 58.4 & 2 & - & - & - & - & - & - \\
\hline Spinosad & - & - & - & - & - & - & - & - & - \\
\hline Etofenprox & $29.7 \pm 7.37 \mathrm{aB}$ & 1.5 & 1 & $27.1 \pm 7.75 \mathrm{aB}$ & 2.3 & 1 & $37.5 \pm 6.01 \mathrm{aA}$ & 0.0 & 1 \\
\hline Triflumuron & $25.5 \pm 5.00 \mathrm{aB}$ & 15.6 & 1 & $37.3 \pm 1.42 \mathrm{aA}$ & 0.0 & 1 & $32.6 \pm 6.67 \mathrm{aA}$ & 0.0 & 1 \\
\hline Alpha-cypermethrin/teflubenzuron & $20.9 \pm 2.05 \mathrm{bB}$ & 30.6 & 2 & $27.4 \pm 3.71 \mathrm{aA}$ & 1.1 & 1 & $33.7 \pm 5.98 \mathrm{aA}$ & 0.0 & 1 \\
\hline Lambda-cyhalothrin/thiamethoxam & $29.8 \pm 10.77 \mathrm{aA}$ & 1.1 & 1 & $30.2 \pm 8.68 \mathrm{aA}$ & 0.0 & 1 & $37.5 \pm 8.71 \mathrm{aA}$ & 0.0 & 1 \\
\hline
\end{tabular}

$\mathrm{CV}, \%=23.2$

${ }^{1}$ Means followed by the same letter, lower-case in column and uppercase in row, are not different by the Scott-Knott test $(\mathrm{P}>0.05)$.

${ }^{2}$ Percentage of reduction in the parasitism capacity.

${ }^{3}$ Class of toxicity proposed by Sterk et al. (1999).

(-)Non evaluated characteristic due to insufficient number of insects.

effects of spinosad on this parameter of $T$. pretiosum was not assessed, regardless of the treated immature stage, because this insecticide reduced in more than $86 \%$ the emergence success of $F_{1}$ adults.

Emergence of adults $\left(\mathrm{F}_{2}\right)$ was significantly reduced by chlorpyrifos, etofenprox, and alpha-cypermethrin/ teflubenzuron, when the egg-larval stage of T. pretiosum $\left(F_{1}\right)$ was treated with these compounds; however, just chlorpyrifos was classified as slightly harmful (class 2), reducing in almost 50\% the emergence success of $\mathrm{F}_{2}$ individuals, while etofenprox and alpha-cypermethrin/ teflubenzuron were considered harmless (class 1) (Table 4). Similar results were observed to beta-cypermethrin, etofenprox, and alpha-cypermethrin/teflubenzuron, for adults emerging from treated pre-pupal stage, when the insecticides were classified as slightly harmful (class 2), harmless (class 1), and harmless (class 1), respectively. None of the evaluated insecticides affected the emergence success of $T$. pretiosum $\left(\mathrm{F}_{2}\right)$ from treated pupae within the host eggs, all of them being classified as harmless (class 1). For the egg-larval stage was not possible to assess the effects of beta-cypermethrin on this biological trait, whereas for both pre-pupal and pupal stages was not possible to assess the effects of chlorpyrifos. As mentioned before for the parasitism capacity, the effects of spinosad on the emergence of $F_{2}$ individuals was not assessed, regardless of the treated immature stage, because this insecticide reduced in almost $100 \%$ the emergence success of $F_{1}$ adults (Tables 1 and 4).

Sex ratio of $\mathrm{F}_{2}$ adults was negatively affected by both chlorfenapyr (pre-pupal stage) and chlorpyrifos (egglarval stage) (Table 5); the effects of chlorpyrifos on this biological trait were not evaluated for the pre-pupal and pupal stages. It was not possible to assess betacypermethrin effects on the egg-larval period, whereas for

Table 5. Sex ratio ( \pm SE) of Trichogramma pretiosum $F_{2}$ from treated eggs of Anagasta kuehniella containing the parasitoids in the immature stages ${ }^{1}$.

\begin{tabular}{lccc}
\hline Treatment & Egg-larvae & Pre-pupae & Pupae \\
\hline Control & $0.65 \pm 0.07 \mathrm{aA}$ & $0.58 \pm 0.10 \mathrm{aA}$ & $0.60 \pm 0.09 \mathrm{aA}$ \\
Beta-cypermethrin & - & $0.57 \pm 0.04 \mathrm{aA}$ & $0.66 \pm 0.06 \mathrm{aA}$ \\
Chlorfenapyr & $0.59 \pm 0.05 \mathrm{aA}$ & $0.41 \pm 0.03 \mathrm{bB}$ & $0.59 \pm 0.02 \mathrm{aA}$ \\
Chlorpyrifos & $0.42 \pm 0.15 \mathrm{~b}$ & - & - \\
Spinosad & - & - & - \\
Etofenprox & $0.65 \pm 0.06 \mathrm{aA}$ & $0.64 \pm 0.14 \mathrm{aA}$ & $0.69 \pm 0.08 \mathrm{aA}$ \\
Triflumuron & $0.56 \pm 0.15 \mathrm{aA}$ & $0.57 \pm 0.18 \mathrm{aA}$ & $0.69 \pm 0.09 \mathrm{aA}$ \\
$\begin{array}{l}\text { Alpha-cypermethrin/ } \\
\text { teflubenzuron }\end{array}$ & $0.55 \pm 0.07 \mathrm{aA}$ & $0.68 \pm 0.12 \mathrm{aA}$ & $0.66 \pm 0.08 \mathrm{aA}$ \\
Lambda-cyhalothrin/ & $0.66 \pm 0.05 \mathrm{aA}$ & $0.56 \pm 0.18 \mathrm{aA}$ & $0.61 \pm 0.17 \mathrm{aA}$ \\
thiamethoxam & & & \\
\hline CV $\%=3.7$ & & & \\
\hline
\end{tabular}

${ }^{1}$ Means followed by the same letter, lower-case in the column and uppercase in the row, are not different by the Scott-Knott test $(\mathrm{P}>0.05)$. (-)Non evaluated characteristic due to insufficient number of insects.

Table 4. Emergence success (\%) ( \pm SE) of Trichogramma pretiosum $\mathbf{F}_{2}$ originated from treated eggs of Anagasta kuehniella containing the parasitoids in the immature stages, percentage of reduction (PR) in the emergence success, and toxicological classification according to International Organization for Biological Control (IOBC) ${ }^{1}$.

\begin{tabular}{|c|c|c|c|c|c|c|c|c|c|}
\hline Treatment & Egg-larvae & $\mathrm{PR}^{2}$ & Class $^{3}$ & Pre-pupae ${ }^{1}$ & $\mathrm{PR}^{2}$ & Class $^{3}$ & Pupae & $\mathrm{PR}^{2}$ & Class $^{3}$ \\
\hline Control & $89.6 \pm 9.76 \mathrm{aA}$ & - & - & $85.5 \pm 11.78 \mathrm{aA}$ & - & - & $77.4 \pm 8.52 \mathrm{aA}$ & - & - \\
\hline Beta-cypermethrin & - & - & - & $58.7 \pm 3.12 b B$ & 31.3 & 2 & $82.9 \pm 6.85 \mathrm{aA}$ & 0.0 & 1 \\
\hline Chlorfenapyr & $73.3 \pm 4.92 \mathrm{aA}$ & 18.2 & 1 & $75.1 \pm 10.64 \mathrm{aA}$ & 12.1 & 1 & $72.5 \pm 8.93 \mathrm{aA}$ & 6.3 & 1 \\
\hline Chlorpyrifos & $46.3 \pm 15.65 c$ & 48.4 & 2 & - & - & - & - & - & - \\
\hline Spinosad & - & - & - & - & - & - & - & - & - \\
\hline Etofenprox & $63.4 \pm 9.40 \mathrm{bB}$ & 29.3 & 1 & $71.7 \pm 6.90 \mathrm{bB}$ & 16.1 & 1 & $81.3 \pm 13.66 \mathrm{aA}$ & 0.0 & 1 \\
\hline Triflumuron & $82.6 \pm 11.12 \mathrm{aA}$ & 7.8 & 1 & $76.2 \pm 9.20 \mathrm{aA}$ & 10.9 & 1 & $84.6 \pm 10.65 \mathrm{aA}$ & 0.0 & 1 \\
\hline Alpha-cypermethrin/teflubenzuron & $68.5 \pm 10.99 \mathrm{bB}$ & 23.6 & 1 & $65.8 \pm 10.99 \mathrm{bB}$ & 22.9 & 1 & $87.3 \pm 10.68 \mathrm{aA}$ & 0.0 & 1 \\
\hline Lambda-cyhalothrin/thiamethoxam & $79.6 \pm 7.29 \mathrm{aA}$ & 11.1 & 1 & $86.0 \pm 7.29 \mathrm{aA}$ & 0.0 & 1 & $77.8 \pm 11.40 \mathrm{aA}$ & 0.0 & 1 \\
\hline
\end{tabular}

$\mathrm{CV}, \%=14.0$

${ }^{1}$ Means followed by the same letter, lower-case in the column and uppercase in the row, are nor different by the Scott-Knott test (P $\left.>0.05\right)$.

${ }^{2}$ Percentage of reduction in the emergence success.

${ }^{3}$ Class of toxicity proposed by Sterk et al. (1999).

(-)Non evaluated characteristic due to insufficient number of insects. 
the spinosad its effects on the sex ratio were not assessed during any of the studied developmental immature stages. The others evaluated insecticides were considered innocuous to this parasitoid.

\section{DISCUSSION}

The highest reduction caused by beta-cypermethrin, chlorfenapyr, chlorpyrifos, and spinosad in the emergence success of $T$. pretiosum $\left(\mathrm{F}_{1}\right)$ from treated host eggs containing the egg-larval period can be associated to the higher activity of the larval stage, as well as to the capacity of some chemicals to penetrate through the host chorion, exposing the larvae to a higher contact with these compounds and affecting the parasitoid development (Guifen and Hirai, 1997; Schuld and Schumuck, 2000; Carvalho et al., 2001; Cônsoli et al., 2001; Moura et al., 2005; 2006). It is also supposed that the highest toxicity presented by beta-cypermethrin, chlorfenapyr, chlorpyrifos, and spinosad to $T$. pretiosum can be related to their octanol-water partition coefficient $\left(\log \mathrm{K}_{\mathrm{ow}}\right)$ values (6.60, 4.83, 4.7, and 2.8, respectively), which give to these compounds higher lipophilicity and, consequently, high residues in the chorion of the host egg.

On the other hand, the observed increasing in the percentage of reduction from the egg-larval to the pupal stage, caused by chlorpyrifos and lambda-cyhalothrin/ thiamethoxam can be due to the ingestion of these chemical residues by the parasitoid during the opening of the emergence hole, as also suggested by Cônsoli et al. (2001) and Moura et al. (2006).

Relative to spinosad, the high mortality values observed during any studied immature developmental stages of $T$. pretiosum could be explained by its mode of action, which excites the nervous system by activating the nicotinic receptors of the acetylcholine, causing paralysis of the insects (Cônsoli et al., 2001).

Triflumuron (benzoylphenylurea) belongs to the insect growth regulators (IGRs) chemical class and act by inhibiting or blocking the synthesis of chitin, by interfering with synthesis of the enzyme chitin synthetase in the final step of chitin formation (Leighton et al., 1981); benzoylphenylureas are taken up more by ingestion than by contact, and are more efficient when applied just before the ecdysis, as without chitin, the insect integument becomes thin and fragile, resulting in the disruption of integument during molting and in the death of the treated insect (Croft, 1990). However, considering our findings it was verified that $T$. pretiosum was able to reach the mature larvae even when its host eggs were treated with triflumuron during the egg-larval period, since it was possible to verify the characteristic blackening of the parasitized eggs, as also suggested by Cônsoli et al. (2001).

Our findings for etofenprox are similar to those of Giolo et al. (2006; 2008), who studied the effect of this insecticide $\left(0.015 \mathrm{~g}\right.$ ai $\left.\mathrm{L}^{-1}\right)$ on $T$. pretiosum and Trichogramma atopovirilia Oatman \& Platner, 1983 (egglarval, pre-pupal, and pupal stages) and verified that the emergence of $F_{1}$ adults of both species was not affected by the insecticide, regardless of the immature stage studied, considering it harmless (class 1) to this beneficial.

Sex ratio alterations caused by some pesticides, as verified in this study for $\mathrm{F}_{1}$ and $\mathrm{F}_{2}$ adults of $T$. pretiosum (Tables 2 and 5) were also observed by Moura et al. (2004; 2005) and Souza et al. (2013) for the same Trichogramma species, as well as by other researchers for Trissolcus grandis Thomson, 1861 (Hymenoptera, Scelionidae) (Novozhilov et al., 1973) and Bracon mellitor Say, 1836 (Hymenoptera, Braconidae) (O'Brien et al., 1985). However, the physiological basis that could explain these alterations is not clear. Nevertheless, we suppose that some pesticides could interfere on a non-Mendelian genetic element, a nuclear "extra" or B chromosome named PSR (Paternal Sex Ratio), which was discovered by Werren and Stouthamer (2003). This chromosome found only in male haplodiploids behaves turning eggs destined to develop as females into males that carry the PSR chromosome, distorting the sex ratio of some parasitoid populations. This theory is described and discussed by Russell and Stouthamer (2010).

Observed reductions in the parasitism capacity of $T$. pretiosum females $\left(\mathrm{F}_{1}\right)$ caused by alpha-cypermethrin/ teflubenzuron and chlorpyrifos, as well as the reductions in the emergence success of $\mathrm{F}_{2}$ adults caused by betacypermethrin, chlorpyrifos, etofenprox, and alphacypermethrin/teflubenzuron, reported in this study can be associated to the sublethal effects of these pesticides on this parasitoid. According to Croft (1990), the severity and length of sublethal effects in natural enemies caused by a pesticide or group of pesticides is a result of many chemical and ecological, as well as physiological processes. However, could also be due to the "latent effects" of these pesticides on the parasitoid. Croft (1990) named of latent effects those effects expressed by a life stage of a natural enemy subsequent to the one initially exposed.

\section{CONCLUSIONS}

In conclusion, beta-cypermethrin, chlorfenapyr, chlorpyrifos, and spinosad reduced the emergence success of $\mathrm{F}_{1}$ Trichogramma pretiosum, whereas triflumuron was innocuous to this parasitoid, regardless of the treated immature stage. Parasitism capacity of $\mathrm{F}_{1} T$. pretiosum females from host eggs treated with chlorfenapyr, etofenprox, triflumuron, and lambda-cyhalothrin/ thiamethoxam was not affected, regardless of the treated immature stage. Triflumuron and etofenprox were harmless for all immature developmental stages of $T$. pretiosum and they can be associated with this parasitoid species in IPM programs for controlling Spodoptera 
frugiperda in corn crops. The other tested pesticides need further evaluation under semi-field and field conditions to ensure their toxicity to this parasitoid.

\section{ACKNOWLEDGEMENTS}

The authors thank the CAPES, CNPq and FAPEMIG for the granting of scholarships and financial support, allowing the realization of this research; and to anonymous reviewers for their critical comments on the early version of the manuscript.

\section{LITERATURE CITED}

Beserra, E.B., e J.R.P. Parra. 2003. Comportamento de parasitismo de Trichogramma atopovirilia Oatman \& Platner e Trichogramma pretiosum Riley (Hymenoptera, Trichogrammatidae) emposturas de Spodoptera frugiperda (J.E. Smith) (Lepidoptera, Noctuidae). Revista Brasileira de Entomologia 47:205-209.

Carvalho, G.A., J.R.P. Parra, e G.C. Baptista. 2001. Seletividade de alguns produtos fitossanitários a duas linhagens de Trichogramma pretiosum Riley, 1879 (Hymenoptera: Trichogrammatidae). Ciência e Agrotecnologia 25:583-591.

Cônsoli, F.L., P.S.M. Botelho, and J.R.P. Parra. 2001. Selectivity of insecticides to the egg parasitoid Trichogramma galloi Zucchi, 1988 (Hym., Trichogrammatidae). Journal of Applied Entomology 125:37-43.

Cônsoli, F.L., M.M. Rossi, and J.R.P. Parra. 1999. Developmental time and characteristics of the immature stages of Trichogramma galloi and Trichogramma pretiosum (Hymenoptera: Trichogrammatidae). Revista Brasileira de Entomologia 43:271275.

Croft, B.A. 1990. Arthropod biological control agents and pesticides. Wiley-Interscience, New York, USA.

Figueiredo, M.L.C., A.M.P. Martins Dias, e I. Cruz. 2006. Relação entre a lagarta do cartucho e seus agentes de controle biológico na produção de milho. Pesquisa Agropecuária Brasileira 41:16931698.

Giolo, F.P., A.D. Grützmacher, C.G. Manzoni, W.R. Härter, C. Müller, e R.V. Castilhos. 2006. Toxicidade de pesticidas utilizados na cultura do pessegueiro para estágios imaturos de Trichogramma pretiosum Riley (Hymenoptera: Trichogrammatidae). BioAssay 1:1-7.

Giolo, F.P., A.D. Grützmacher, C.G. Manzoni, S.D. Nörnberg, W.R. Härter, e R.V. Castilho. 2008. Seletividade de produtos fitossanitários utilizados na cultura do pessegueiro nos estágios imaturos de Trichogramma atopovirilia Oatman \& Platner, 1983 (Hymenoptera: Trichogrammatidae). Ciência Rural 38:12201226.

Guifen, Z., and K. Hirai. 1997. Effects of insecticides on developmental stages of Trichogramma japonicum in the laboratory. Proceedings of the Kanto Tosan Plant Protection Society 44:197-200.

IBGE/LSPA. 2013. Instituto Brasileiro de Geografia e Estatística (IBGE), Rio de Janeiro, Brasil. Levantamento sistemático da produção agrícola. Available at http://www.ibge.gov.br/home/ estatistica/indicadores/agropecuaria/lspa/1spa_201304.pdf (accessed June 2013).

Leighton, T., E. Marks, and F. Harghton. 1981. Pesticides: insecticides and fungicides are chitin synthesis inhibitors. Science 213:905-907.
Moura, A.P., G.A. Carvalho, V.F. Moscardini, O. Lasmar, D.T. Rezende, and M.C. Marques. 2010. Selectivity of pesticides used in integrated apple production to the lacewings, Chrysoperla externa. Journal of Insect Science 10(121):1-20.

Moura, A.P., G.A. Carvalho, A.E. Pereira, and L.C.D. Rocha. 2006. Selectivity evaluation of insecticides used to control tomato pests to Trichogramma pretiosum. BioControl 51:769-778.

Moura, A.P., G.A. Carvalho, e R.L.O. Rigitano. 2004. Efeito residual de novos inseticidas utilizados na cultura do tomateiro sobre Trichogramma pretiosum Riley, 1879 (Hymenoptera: Trichogrammatidae). Acta Scientiarum. Agronomy 26:231-237.

Moura, A.P., G.A. Carvalho, e R.L.O. Rigitano. 2005. Toxicidade de inseticidas utilizados na cultura do tomateiro a Trichogramma pretiosum. Pesquisa Agropecuária Brasileira 40:203-210.

Novozhilov, K.V., K.V. Kamenkova, and I.M. Smirnova. 1973. Development of the parasite Trissolcus grandis Thoms. (Hymenoptera, Scelionidae) where organophosphorus insecticides are in use against Eurygaster integriceps Put. (Hemiptera, Scutelleridae). Entomologicheskoe Obozrenie 52:20-28.

O'Brien, P.J., G.W. Elzen, and S.B. Vinson. 1985. Toxicity of azinphosmethyl and chlordimeform to parasitoid Bracon mellitor (Hymenoptera: Braconidae): lethal and reproductive effects. Environmental Entomology 14:891-894.

Parra, J.R.P. 1997. Técnicas de criação de Anagasta kuehniella, hospedeiro alternativo para produção de Trichogramma. p. 121150. In J.R.P. Parra and R.A. Zucchi (eds.) Trichogramma e o controle biologico aplicado. Fundação de Estudos Agrários "Luiz de Queiroz" (FEALQ), Piracicaba, São Paulo, Brasil.

Querino, R.B., and R.A. Zucchi. 2005. An illustrated key to the species of Trichogramma (Hymenoptera: Trichogrammatidae) recorded in Brazil. Zootaxa 1073:37-70.

Querino, R.B., e R.A. Zucchi. 2011. Guia de identificação de Trichogramma para o Brasil. 103 p. Embrapa Informação Tecnológica, Brasília, Brasil.

Russell, J.E., and R. Stouthamer. 2010. Sex ratio modulators of egg parasitoids. p. 167-190. In Cônsoli, F.L., J.R.P. Parra, and R.A. Zucchi (eds.) Egg parasitoids in agroecosystems with emphasis on Trichogramma. Springer, Dordrecht, The Netherlands.

SAS Institute. 2001. SAS/STAT User's guide: Statistics. SAS Institute, Cary, North Carolina, USA.

Schuld, M., and R. Schumuck. 2000. Effects of thiacloprid, a new chloronicotinil insecticide, on the egg parasitoid Trichogramma cacoeciae. Ecotoxicology 9:197-205.

Scott, A.J., and M.A. Knott. 1974. A cluster analysis method for grouping means in the analysis of variance. Biometrics 30:507512.

Souza, J.R., G.A. Carvalho, A.P. Moura, M.H.G. Couto, and J.B. Maia. 2013. Impact of insecticides used to control Spodoptera frugiperda (J.E. Smith) in corn on survival, sex ratio, and reproduction of Trichogramma pretiosum Riley offsprings. Chilean Journal of Agricultural Research 73:122-127.

Sterk, G., S.A. Hassan, M. Baillod, F. Bakker, F. Bigler, S. Blümel, et al. 1999. Results of the seventh joint pesticide testing programmer carried out by the IOBC/WPRS-Working Group 'Pesticides and Beneficial Organisms'. BioControl 44:99-117.

Werren, J.H., and R. Stouthamer. 2003. PSR (paternal sex ratio) chromosomes: the ultimate selfish genetic elements. Genetica 117:85-101.

Zucchi, R.A., R.B. Querino, and R.C. Monteiro. 2010. Diversity and hosts of Trichogramma in the New World, with emphasis in South America. p. 219-236. In Cônsoli, F.L., J.R.P. Parra, and R.A. Zucchi (eds.) Egg parasitoids in agroecosystems with emphasis on Trichogramma. Springer, Dordrecht, The Netherlands. 